\title{
Emission characteristics using methyl soyate-ethanol-diesel fuel blends on a diesel engine
}

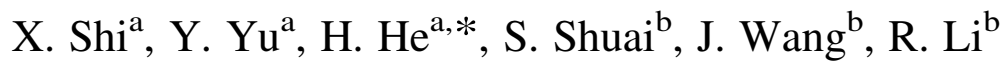 \\ ${ }^{a}$ State Key Laboratory of Environmental Chemistry and Ecotoxicology, Research Center for Eco-environmental Sciences, \\ Chinese Academy of Sciences, Beijing 100085, China \\ ${ }^{\mathrm{b}}$ State Key Laboratory of Automotive Safety and Energy, Tsinghua University, Beijing 100084, China
}

Received 16 October 2004; received in revised form 7 March 2005; accepted 8 March 2005

Available online 1 April 2005

\begin{abstract}
A blend of $20 \%(\mathrm{v} / \mathrm{v})$ ethanol/methyl soyate was prepared and added to diesel fuel as an oxygenated additive at volume percent levels of 15 and 20\% (denoted as BE15 and BE20). We also prepared a blend containing 20\% methyl soyate in diesel fuel (denoted as B20). The fuel blends that did not have any other additive were stable for up to 3 months. Engine performance and emission characteristics of the three different fuels in a diesel engine were investigated and compared with the base diesel fuel. Observations showed that particulate matter (PM) emission decreased with increasing oxygenate content in the fuels but nitrogen oxides $\left(\mathrm{NO}_{x}\right)$ emissions increased. The diesel engine fueled by BE20 emitted significantly less PM and a lower Bosch smoke number but the highest $\mathrm{NO}_{x}$ among the fuel blends tested. All the oxygenate fuels produced moderately lower CO emissions relative to diesel fuel. The B20 blend emitted less total hydrocarbon (THC) emissions compared with base diesel fuel. This was opposite to the fuel blends containing ethanol (BE15, BE20), which produced much higher THC emission.
\end{abstract}

(C) 2005 Elsevier Ltd. All rights reserved.

Keywords: Diesel engine; Oxygenate fuel; Emissions reduction

\section{Introduction}

Oxygenated fuels are known to reduce PM emissions for motor vehicles and have been evaluated as potential sources of renewable fuels. Among the alternative fuels, biodiesel and ethanol are the most widely studied biofuels for diesel engines and have received considerable attention in recent years [1-19]. Biodiesel has properties similar to those of traditional diesel such that it can be substituted for diesel fuel with little or no engine modification. Biodiesel has been recognized as an environment friendly alternative fuel for diesel engines. The most widely used form of biodiesel is made from

\footnotetext{
* Corresponding author. Address: Research Center for Eco-environmental Sciences, ACS, Air Pollution Control Technology, P.O. Box 2871, 18 Shuangqing Road, Beijing 100085, China. Tel.: + 861062849123 ; fax: + 86 1062923563 .

E-mail address: honghe@mail.rcees.ac.cn (H. He).
}

0016-2361/\$ - see front matter (C) 2005 Elsevier Ltd. All rights reserved. doi:10.1016/j.fuel.2005.03.001 methanol and soybean oil and is known as methyl soyate, or soy methyl ester.

Graboski and co-workers tested primarily methyl esters of various fats and oils in neat or blended form in diesel engines [1]. They found that the lubricity of these fuels was superior to conventional diesel fuel, and this property was imparted to blends at levels above 20 vol\% by volume. Emissions of PM can be reduced dramatically through the use of biodiesel in engines. Emissions of $\mathrm{NO}_{x}$ increased significantly for both neat and blended fuels in both twoand four-stroke engines. Ali et al. also employed a DD6V92TA engine and a Cummins NTA-855-C engine to determine the power characteristics and emissions of $\mathrm{NO}_{x}$, $\mathrm{HC}, \mathrm{CO}$ and Bosch smoke that resulted from blending methyl soyate and diesel fuel [4]. Their results showed that there was no significant reduction in engine power output on methyl soyate blends up to $30 \%$ in volume and as the percentage of methyl soyate in the fuel increased, the $\mathrm{NO}_{x}$ increased but the $\mathrm{HC}, \mathrm{CO}$ and Bosch smoke decreased. Wang et al. employed nine tractor trucks to determine the emissions from a blend of 35\% biodiesel and 65\% petroleum diesel, designated as B35 [5]. The test showed 
that the heavy-duty trucks fueled by B35 emitted markedly lower PM, CO and $\mathrm{HC}$ compared to emissions with diesel fuel. The heavy duty trucks tested performed well when the diesel engine was fueled with B35 without any modification.

McCormick and coworkers investigated several oxygenates, n-octanol (C8), decanoic acid (C12), and methyl soyester (C17) at $1 \mathrm{wt} \%$ oxygen in diesel fuel using a 6V-92TA DEC II engine [6]. It was found that all oxygenates tested produced a significant PM reduction in the range of $12-17 \%$. This study also examined the effect of methyl soy ester and $n$-octanol at $2 \mathrm{wt} \%$ oxygen on a DDC Series 60 engine. Methyl soy ester and $n$-octanol produced 20 and $12 \%$ reductions in particulate matter (PM), respectively. The effect of oxygenates on $\mathrm{NO}_{x}$ emissions was different. Methyl ester increased $\mathrm{NO}_{x}$ by $2-3 \%$, while decanoic acid had no effect on $\mathrm{NO}_{x}$, and octanol slightly decreased $\mathrm{NO}_{x}$ emissions [6].

On the other hand, studies on ethanol-diesel confirm substantial reductions in PM [7-11]. However, there are many technical barriers to the direct use of ethanol in diesel fuel because of the properties of ethanol: for instance, the low cetane number of ethanol and the solubility of ethanol in diesel fuel at a wide range of temperature. In fact, diesel engines cannot operate normally on an ethanol-diesel blend without special additives. Despite these facts, ethanol is still a low cost oxygenate with high oxygen content [12]. Blending ethanol with diesel produces an effective blended fuel.

The studies cited above clearly indicate that a substantial reduction in PM emissions can be obtained through the addition of oxygenates, and in particular, biodiesel and ethanol, to diesel fuel.

Previous studies have suggested that for PM reduction, the weight percent of oxygen content in the fuel is the most important factor; it is more important than other properties such as chemical structure or volatility $[1,5,13]$. The oxygen content of ethanol is much higher than that of methyl soyate. Including ethanol in biodiesel and diesel blends can increase the fuel oxygen level. On the other hand, biodiesel is known to act as an emulsifier for ethanol. Solubility and stability of ethanol in fuel blends will be greatly improved without other additives [7]. Additionally, the poor cold flow properties of biodiesel is a barrier to the use of biodiesel and diesel fuels blends in cold weather. The average freezing point of soybean methyl ester was reported to be $-3.8^{\circ} \mathrm{C}$ [2]. Ethanol might be expected to improve low temperature flow properties. It is assumed that the high cetane number of biodiesel can compensate for the cetane number decrease caused by the presence of ethanol in fuel. Taking these facts into account, it was assumed that blends of biodiesel, ethanol, and diesel fuel may improve some properties compared with biodiesel-diesel blends and ethanol-diesel blends.

Ali et al. used 12 different blends of methyl tallowate, methyl soyate, ethanol and diesel fuel in a Cummins N14-410 diesel engine and found that engine performance with these fuel blends did not differ to a great extent from engine performance with diesel fuel [14]. In their study, the same engine fueled by an 80:13:7 blend of diesel fuel:methyl tallowate:ethanol emitted minimum emissions [15]. It has been suggested that the biodiesel and ethanol blends can be an optimized oxygenate for diesel fuels [7].

In the current study, we investigated the engine performance and emissions characteristics with fuel blends of petroleum diesel fuel, methyl soyate, and ethanol on a diesel engine. Brake specific fuel consumption (BSFC), regulated emissions, including $\mathrm{PM}$, Bosch smoke number, nitrogen oxide $\left(\mathrm{NO}_{x}\right)$, carbon monoxide $(\mathrm{CO})$ and total unburned hydrocarbon (THC), were investigated and discussed. Water tolerance and stability of the blends fuels were also considered.

\section{Experimental}

\subsection{Engine and apparatus}

All experiments were performed on a commercial DI diesel engine, named Sofim 8140.43C, which met Euro II emission regulations. The major engine specifications are shown in Table 1. Prior to running each experiment, the engine was fully warmed and the injection pressure was adjusted by an outside pressure compensation instrument to ensure the engine operated at the same injection pressure for each fuel. A Zöllner electric eddy dynamometer was coupled to the engine and used to measure the engine power. An exhaust gases analyzer (AVL CEB-11 type) was employed to measure the emissions of $\mathrm{NO}_{x}, \mathrm{THC}, \mathrm{CO}$ and $\mathrm{CO}_{2}$ on line. The relative standard deviations of $\mathrm{NO}_{x}$, $\mathrm{CO}$, THC, and $\mathrm{CO}_{2}$ concentrations were $<1,<5,<3$ and $<0.2 \%$, respectively. The Bosch smoke number was measured with a FBY-1 smoke analyzer. Total PM was measured by an AVL PM analyzer with exhaust particulate dilution and a sampling system.

Two types of experimental units were carried out in the current study: speed characteristics (engine performance at various speeds with full load, denoted by Run 1) and load characteristics (engine performance at peak torque speed, 1900 rpm, with varying loads, denoted by Run 2), as shown in Table 2.

Table 1

Engine specifications

\begin{tabular}{ll}
\hline Cylinder number & 4 \\
Bore $(\mathrm{mm}) \times$ stroke $(\mathrm{mm})$ & $94.4 \times 100$ \\
Displacement $(\mathrm{L})$ & 2.8 \\
Compression ratio & $18.5: 1$ \\
Rated power $(\mathrm{kW}) / \mathrm{speed}(\mathrm{r} / \mathrm{min})$ & $76 / 3600$ \\
Maximum torque $(\mathrm{Nm}) /$ speed $(\mathrm{r} / \mathrm{min})$ & $245 / 1900$ \\
\hline
\end{tabular}


Table 2

Experimental conditions

\begin{tabular}{|c|c|c|c|c|c|}
\hline \multicolumn{3}{|l|}{ Run 1} & \multicolumn{3}{|l|}{ Run 2} \\
\hline $\begin{array}{l}\text { Speed } \\
\text { (rpm) }\end{array}$ & $\begin{array}{l}\text { Torque } \\
(\mathrm{N} \mathrm{m})\end{array}$ & $\begin{array}{l}\text { Power } \\
(\mathrm{kW})\end{array}$ & $\begin{array}{l}\text { Speed } \\
(\mathrm{rpm})\end{array}$ & $\begin{array}{l}\text { Torque } \\
(\mathrm{N} \mathrm{m})\end{array}$ & $\begin{array}{l}\text { Power } \\
(\mathrm{kW})\end{array}$ \\
\hline 1100 & 150 & 17 & 1900 & 25 & 5 \\
\hline 1600 & 220 & 36 & 1900 & 62 & 12 \\
\hline 1900 & 251 & 49 & 1900 & 125 & 25 \\
\hline 2400 & 230 & 61 & 1900 & 187 & 37 \\
\hline 2900 & 220 & 66 & 1900 & 210 & 43 \\
\hline 3600 & 186 & 70 & 1900 & 249 & 49 \\
\hline
\end{tabular}

\subsection{Experimental fuels}

The commercial diesel fuel employed in the tests was obtained locally. The methyl soy ester was produced in China. It was made through a reaction of soybean oil and methanol, and was provided by a local supplier. The ethanol was an analysis-grade anhydrous ethanol (99.7\% purity).

Viscosity was determined by the standard test method (GB/T 265-88, China). The temperature of the sample was maintained at $40{ }^{\circ} \mathrm{C}$ within $\pm 0.1{ }^{\circ} \mathrm{C}$ with a constant temperature bath. Five viscosity measurements were made on each sample and average was taken.

The viscosity of methyl soyate was observed to be $4.75 \mathrm{cS}$, much higher than that of diesel fuel at $40{ }^{\circ} \mathrm{C}$. It was observed that a blend of $20 \%(\mathrm{v} / \mathrm{v})$ ethanol with methyl soyate had the same viscosity as diesel fuel at $40{ }^{\circ} \mathrm{C}$. In the current study, an oxygenate consisting of $20 \%$ (v/v) ethanol with methyl soyate (denoted by BE) was added to the base diesel fuel at different percent volumes.

Four fuels were prepared: diesel fuel as baseline fuel, 20 vol\% methyl soyate and diesel fuel blends (denoted by B20), $15 \mathrm{vol} \% \mathrm{BE}$ (a blend of $20 \%$ (v/v) ethanol with methyl soyate) and diesel fuel blends (denoted by BE15), 20 vol\% BE and diesel fuel blends (denoted by BE20). B20, BE15, and BE20 were very stable even when exposed to air for at least 3 months. The water tolerance of BE15 and BE 20 was observed to be about $1 \sim 2 \%$ at $20{ }^{\circ} \mathrm{C}$.

Some of their properties are reported in Tables 3 and 4.

Table 3

Properties of blending stocks

\begin{tabular}{llll}
\hline Properties & Diesel & Methyl soyate & Ethanol \\
\hline Boiling point $\left({ }^{\circ} \mathrm{C}\right)$ & $180-330$ & 330 & 78 \\
Cloud point $\left({ }^{\circ} \mathrm{C}\right)$ & -5 & 0 & - \\
Density, g/ml at $20{ }^{\circ} \mathrm{C}$ & 0.84 & 0.88 & 0.789 \\
Oxygenate $(\mathrm{wt} \%)$ & $\mathrm{n} / \mathrm{a}$ & 11 & 35 \\
Carbonate $(\mathrm{wt} \%)$ & 87 & 77 & 52 \\
Hydrogen $(\mathrm{wt} \%)$ & 13 & 11.8 & 13 \\
Viscosity, $\mathrm{cS}$ at $40{ }^{\circ} \mathrm{C}$ & 3.11 & 4.75 & 1.2 \\
Cetane number & 46 & 55 & 6 \\
Flash point $\left({ }^{\circ} \mathrm{C}\right)$ & 78 & 66 & 13.5 \\
Gross heat content $(\mathrm{MJ} / \mathrm{kg})$ & 42.5 & 38.0 & 27.0 \\
\hline
\end{tabular}

Table 4

Properties of fuel blends

\begin{tabular}{lllllll}
\hline & $\begin{array}{l}\text { Ethanol, } \\
\%(\mathrm{v} / \mathrm{v})\end{array}$ & $\begin{array}{l}\text { Methyl } \\
\text { soyate, } \\
\%(\mathrm{v} / \mathrm{v})\end{array}$ & $\begin{array}{l}\text { Oxyge- } \\
\text { nate } \\
(\mathrm{wt} \%)\end{array}$ & $\begin{array}{l}\text { Vis- } \\
\text { cosity, } \\
\mathrm{cS}, \text { at } \\
40^{\circ} \mathrm{C}\end{array}$ & $\begin{array}{l}\text { Density, } \\
\mathrm{g} / \mathrm{ml} \text { at } \\
20{ }^{\circ} \mathrm{C}\end{array}$ & $\begin{array}{l}\text { Gross } \\
\text { heat } \\
\text { content } \\
(\mathrm{MJ} / \mathrm{kg})\end{array}$ \\
\hline Diesel & 0 & 0 & 0 & 3.11 & 0.84 & 42.5 \\
B20 & 0 & 20 & 2.3 & 3.36 & 0.85 & 41.6 \\
BE15 & 3 & 12 & 2.3 & 3.01 & 0.84 & 41.5 \\
BE20 & 4 & 16 & 3.1 & 3.03 & 0.84 & 41.2 \\
\hline
\end{tabular}

\section{Results and discussion}

\subsection{Brake specific fuel consumption (BSFC)}

The BSFC measurements for all fuels at Run 1 operation conditions are shown in Fig. 1. The differences in BSFC reflected the differences in some of the physical properties of the fuels such as density and calorific values. Calorific values of ethanol and methyl soyate are lower than that of diesel fuel. The gross heat value of diesel was $42.5 \mathrm{MJ} / \mathrm{kg}$, whereas that of BE20 was only $41.2 \mathrm{MJ} / \mathrm{kg}$, a drop of about $3 \%$. In theory, the BSFC should increase with an increase in the oxygenate content in the fuel blends because of the reduced energy content. In the current study, the fuel blends showed very slight change in BSFC compared with diesel fuel. The engine performance was little affected by the lower gross heat value of the oxygenate fuels.

\subsection{Smoke emissions and total particulate matter (PM)}

The Bosch smoke number was measured for D, B20, BE15 and BE20 in the engine at Run 1 (Fig. 2a) and at Run 2 (Fig. 2b) operation conditions. From Fig. 2, it is obvious that the smoke emissions were reduced with the oxygenated fuels and were decreased most with BE20 under the operation conditions. Adding oxygenates to diesel fuel had a remarkable effect on the reduction of smoke emissions, especially at high load at the engine speed of $1900 \mathrm{rpm}$ (Fig. 2b). With the BE20, an average $47 \%$ reduction of Bosch smoke number was obtained at Run 1

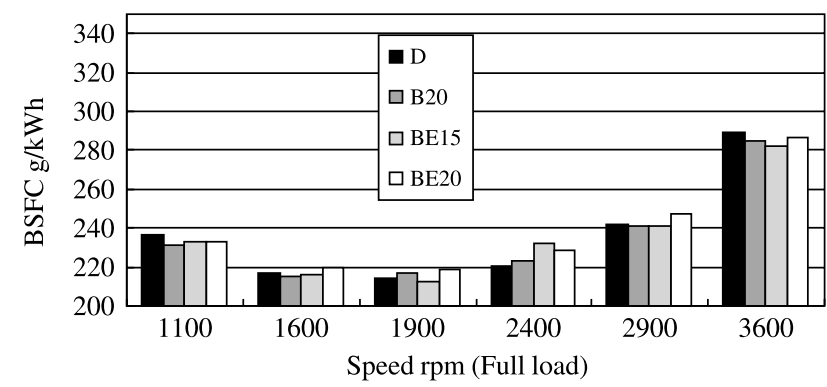

Fig. 1. Comparison of BSFC for test fuels at various engine speeds. D: diesel fuel; B20:20:80 (v/v) blend of methyl soyate:diesel fuel. BE15:12:3:85 (v/v) blend of methyl soyate:ethanol:diesel fuel. BE20:16:4:80 (v/v) blend of methyl soyate:ethanol:diesel fuel. 
(a)

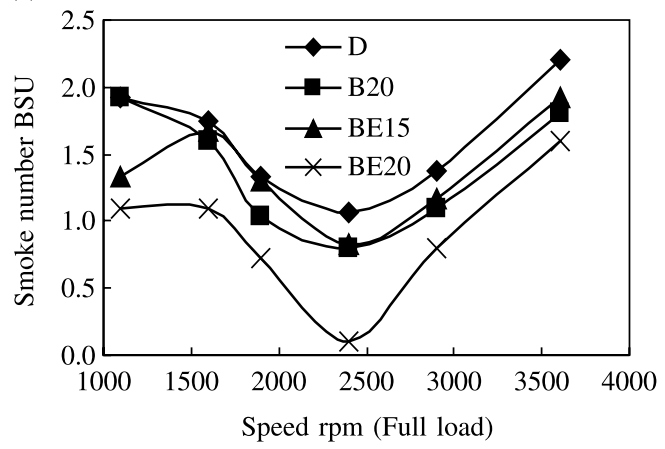

(b)

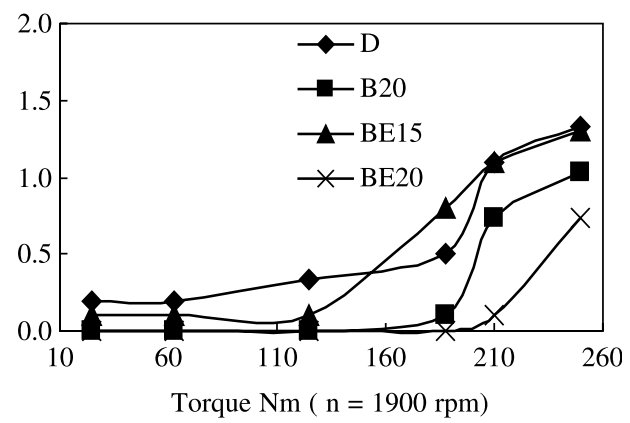

Fig. 2. Comparison of Bosch smoke number for test fuels, a: full load; b: $n=1900 \mathrm{rpm}$. D: diesel fuel; B20:20:80 (v/v) blend of methyl soyate: diesel fuel. BE15:12:3:85 (v/v) blend of methyl soyate:ethanol:diesel fuel. BE20:16:4:80 (v/v) blend of methyl soyate:ethanol:diesel fuel.

(Fig. 2a), and a $90 \%$ reduction of this number was obtained at $210 \mathrm{~N} \mathrm{~m}$ load at the engine speed of $1900 \mathrm{rpm}$ (Fig. 2b). The reduction of smoke emissions can be explained by the enrichment of oxygen content in the fuel by the addition of oxygenates (methyl soyate and ethanol), resulting in more complete combustion.

Fig. 3 shows the total PM emission results obtained from the fuels at the maximum torque and at the highest engine speed. The results demonstrate that B20, BE15, and BE20 decreased the total PM emissions greatly. PM reduction of B20 was very close to that of BE15; it was $34 \%$ at the highest speed and was $17 \%$ at the maximum torque. BE20 showed the largest decreases in PM among the test fuels as expected, which produced 48 and $34 \%$ reduction in PM at the two operation points. It should be noted that the results of PM emissions are preliminary since only a limited number of runs were completed in this study. However, considering the results of smoke emission, which is closely related to PM emission, adding ethanol to biodiesel and diesel fuel blends results in significant improvement PM emissions.

\section{3. $N O_{x}$ emissions}

In the current investigation, it is apparent that $\mathrm{NO}_{x}$ emissions varied considerably with the test fuels at selected operating conditions. All fuel blends increased $\mathrm{NO}_{x}$ relative to diesel fuel. Normally, if we can organize a more complete combustion, we can get a higher combustion temperature, which will cause a high $\mathrm{NO}_{x}$ formation. It should be noted that oxygenates are blended with the fuel at the same volume percent level for B20 and BE20; however, the $\mathrm{NO}_{x}$ increase with BE20 was more significant than that with B20, which means that the ethanol might have a more complete combustion than the methyl soyate. On the other hand, B20 and BE15 have equal oxygen content weights; however, the $\mathrm{NO}_{x}$ emissions with BE15 were measurably higher than those with B20, which again proved the ethanol's effect on combustion. From Fig. 4, it is evident that the $\mathrm{NO}_{x}$ emissions decreased with increasing torque. At a full load,
$\mathrm{NO}_{x}$ emissions varied with engine speeds and the peak of $\mathrm{NO}_{x}$ emissions occurred from 1600 to $2900 \mathrm{rpm}$, where the highest combustion temperature was occurred in maximum torque region. The highest $\mathrm{NO}_{x}$ emissions among the fuels tested were observed with the use of BE20. $\mathrm{NO}_{x}$ emissions with BE20 increased about $19 \%$ at Run 1 (Fig. 4a) and increased about $30 \%$ at Run 2 (Fig. 4b), compared with diesel fuel.

The increase of the $\mathrm{NO}_{x}$ emissions can be explained by the decrease of the cetane number with the addition of the oxygenates. It is well known that the cetane number has a significant influence on combustion. A lower cetane number means an increase in the ignition delay and more accumulated fuel/air mixture, which causes a steep heat release in the beginning of the combustion, resulting in high temperatures and high $\mathrm{NO}_{x}$ formation. The cetane number of the fuel decreased with the increase of ethanol content in the fuel because of the low cetane number of ethanol. For BE15 and BE20, the cetane number should be the dominant factor for increased $\mathrm{NO}_{x}$ emissions. In addition, we observed a measurable increase of the concentration of oxygen presence in combustion products with BE15 and a slight increase of that with BE 20 (not shown here). This may be another cause for $\mathrm{NO}_{x}$ increase.

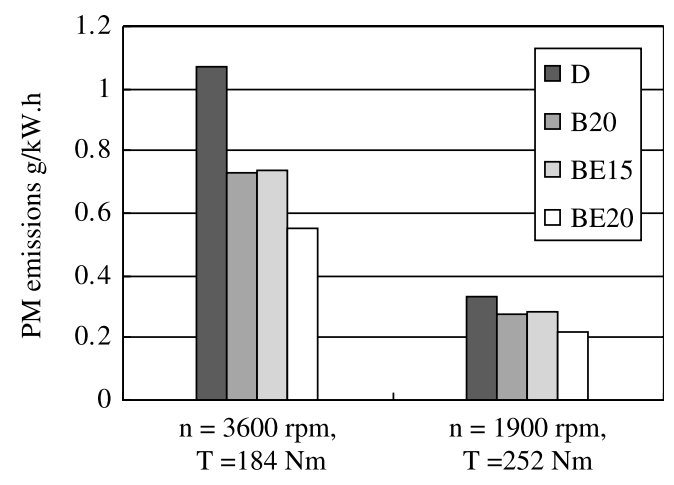

Fig. 3. Comparison of PM emissions for test fuels. D: diesel fuel. B20:20:80 $(\mathrm{v} / \mathrm{v})$ blend of methyl soyate:diesel fuel. BE15:12:3:85 (v/v) blend of methyl soyate:ethanol: diesel fuel. BE20:16:4:80 (v/v) blend of methyl soyate:ethanol:diesel fuel. 
(a)

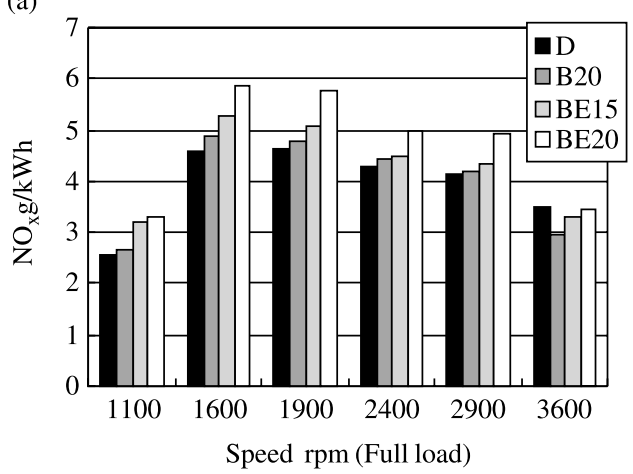

(b)

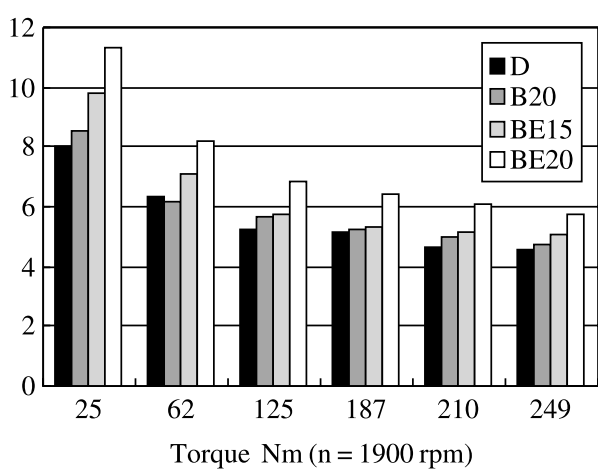

Fig. 4. Comparison of $\mathrm{NO}_{x}$ emissions for test fuels, a: full load; b: $n=1900 \mathrm{rpm}$. D: diesel fuel; B20:20:80 (v/v) blend of methyl soyate:diesel fuel. BE15:12:3:85 (v/v) blend of methyl soyate:ethanol:diesel fuel. BE20:16:4:80 (v/v) blend of methyl soyate:ethanol:diesel fuel.

It should be noted that the $\mathrm{B} 20$ fuel increased $\mathrm{NO}_{x}$ but had a substantially higher cetane number than diesel fuel because of the high cetane number of methyl soyate. The $\mathrm{NO}_{x}$ behavior of biodiesel blended fuels is complex and is not conclusive. Many studies indicate that oxygenate fuel blends can cause the increase of $\mathrm{NO}_{x}$ emissions. However, some studies also found no $\mathrm{NO}_{x}$ increase or even a decease in $\mathrm{NO}_{x}$ [16]. There is strong evidence that methyl soyate can cause the increase of $\mathrm{NO}_{x}$ emissions and many explanations for the increase of $\mathrm{NO}_{x}$ during biodiesel combustion have been proposed $[1,4,5,13]$. In the case of ethanol-diesel blended fuel, some studies reported a significant benefit in terms of $\mathrm{NO}_{x}$ emissions [17,18]. However, some opposite results have also been reported and explained [19].

\subsection{THC emissions}

Fig. 5 shows that $\mathrm{HC}$ emissions decreased when the diesel engine was fueled with B20, and the reduction rates were about $21 \%$ at Run 1 (Fig. 5a) and about 23\% at Run 2 (Fig. 5b) operation conditions. On the other hand, the THC emissions with BE15 and BE20 increased significantly relative to that with diesel fuel at all selected operation conditions. This indicates that the presence of ethanol might be the essential factor for the increase of THC emissions

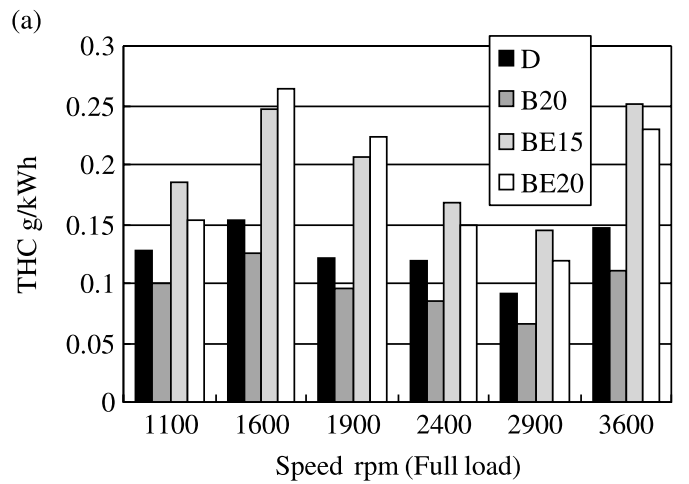

with BE15 and BE20. High THC emission means that there is some unburned ethanol emitted in the exhaust due to the larger ethanol dispersion region in the combustion chamber. Methyl soyate has a higher cetane number than diesel, which will result in more complete combustion in the cylinder. Thus, B20 had less THC emissions than diesel fuel.

\subsection{CO emissions}

The variations of $\mathrm{CO}$ emission with respect to fuels, loads and engine speeds are shown in Fig. 6. The overall test results showed that BE20 reduced $\mathrm{CO}$ emissions by an average of about $19 \%$ at Run 1 (Fig. 6a) and $20 \%$ at Run 2 (Fig. 6b). B20 and BE15 showed similar CO emissions characteristics and reduced $\mathrm{CO}$ emissions slightly compared with the base diesel fuel. This is understandable because the blends fuels have higher oxygen content than diesel fuel. BE20 contains $3.1 \%$ oxygen and produced the smallest amount of $\mathrm{CO}$ among the four fuels. The $\mathrm{CO}$ emissions of the four fuels showed similar trends at all the selected operation conditions. For a steady engine speed of $1900 \mathrm{rpm}$ (Fig. 6b), $\mathrm{CO}$ emissions increased markedly at lower and higher loads. For a full load, high $\mathrm{CO}$ emissions were observed at lower speeds and higher speeds (Fig. 6a). (b)

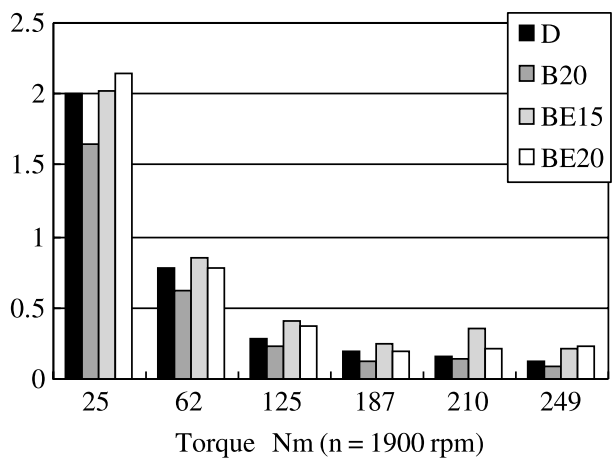

Fig. 5. Comparison of THC emissions, a: full load; b: $n=1900$ rpm. D: diesel fuel; B20:20:80 (v/v) blend of methyl soyate:diesel fuel. BE15:12:3:85 (v/v) blend of methyl soyate:ethanol:diesel fuel. BE20:16:4:80 (v/v) blend of methyl soyate:ethanol:diesel fuel. 
(a)

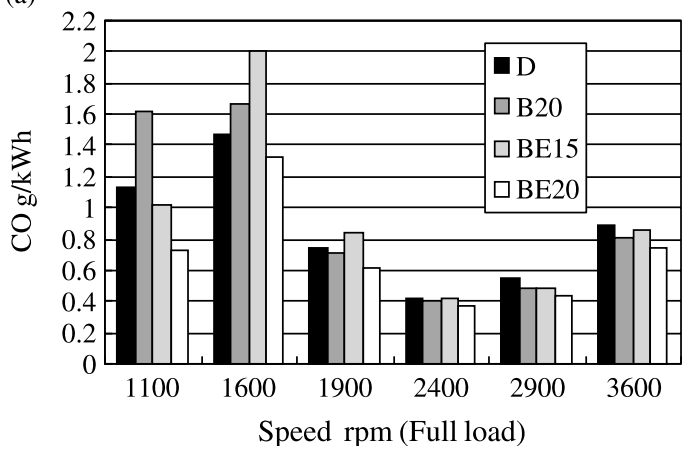

(b)

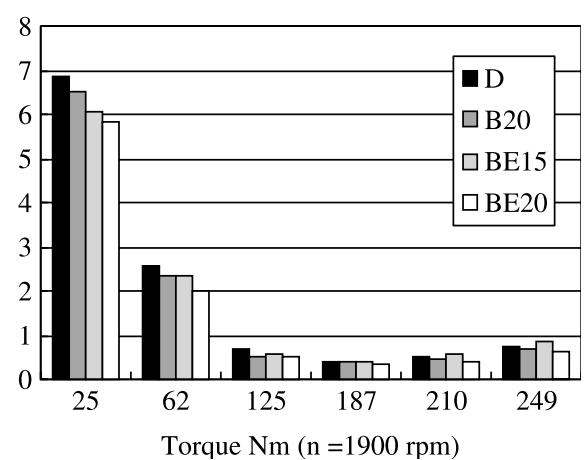

Fig. 6. Comparison of CO emissions, a: full load; b: $n=1900 \mathrm{rpm}$. D: diesel fuel; B20:20:80 (v/v) blend of methyl soyate: diesel fuel. BE15:12:3:85 (v/v) blend of methyl soyate:ethanol:diesel fuel. BE20:16:4:80 (v/v) blend of methyl soyate:ethanol:diesel fuel.

Normally, better combustion can be achieved at a medium speed and with a medium-sized load. The addition of oxygenates into the diesel fuel results in a slight benefit in the reduction of $\mathrm{CO}$.

\section{Conclusions}

The results indicated that the presence of oxygenated compounds in diesel fuels significantly influences engine emissions. All oxygenated fuels tested show a beneficial effect on reducing smoke emissions and PM emissions at the operation conditions compared with diesel fuel. Consistent with other studies, the PM emissions were largely dependent on the oxygen content of the fuel. BE20, which has the highest oxygen weight content in all tested fuels in this study, showed excellent ability to eliminate soot emissions, and the maximum reduction of PM was observed at $48 \%$. $\mathrm{NO}_{x}$ emissions were observed to increase when oxygenated fuels were used. An average increase in $\mathrm{NO}_{x}$ emission was $25 \%$ at Run 1 and $32 \%$ at Run 2 . The CO emissions with BE15 and B20 were slightly lower than that with diesel fuel. $\mathrm{BE} 20$ decreased $\mathrm{CO}$ emissions relative to diesel fuel. BE15 and BE20 increased THC emissions while B20 decreased the THC compared with diesel fuel. In this case, ethanol content may be the essential factor in the THC emission. Despite the unwanted results of the increase in $\mathrm{NO}_{x}$ emissions and THC emissions on the biodiesel/ethanol/ diesel blends, the apparent large decrease in PM emission for these blended fuels is promising and should attract the interest of some researchers. Additionally, our previous works has proven that catalytic treatment is an effective way to control the $\mathrm{NO}_{x}$ emissions from diesel engines [20-22]. A rather high $\mathrm{NO}_{x}$ emission reduction rate has been obtained by applying our catalytic converter to a diesel engine in our previous experiment. In addition, biodiesel/ethanol/diesel blends show better properties of water tolerance and stability than biodiesel-diesel and ethanol-diesel. Taking these facts into account, the biodiesel, ethanol and diesel fuel blends can be considered to be promising alternative fuels for diesel engines.

\section{Acknowledgements}

This work was financially supported by the Innovation Program of Chinese Academy of Sciences (KZCX3-SW-430).

\section{References}

[1] Graboski MS, McCormick RL, Alleman TL, Herring AM. The effect of biodiesel composition on engine emissions from a DDC Series 60 diesel engine. Final Report to NREL/SR-510-31461; February, 2003.

[2] Graboski MS, McCormick RL. Combustion of fat and vegetable oil derived fuels in diesel engines. Prog Energy Combust Sci 1998;24: 125-64.

[3] Hansen AC, Zhang Q, Lyne PWL. Ethanol-diesel fuel blends-a review. Bioresour Technol 2005;96:277-85.

[4] Ali Y, Hanna MA, Leviticus LI. Emissions and power characteristics of diesel engines on methyl soyate and diesel fuel blends. Bioresour Technol 1995;52:185-95.

[5] Wang WG, Lyons DW, Clark NN, Gautam M. Emissions from nine heavy trucks fueled by diesel and biodiesel blend without engine modification. Environ Sci Technol 2000;34:933-9.

[6] McCormick RL, Ross JD, Graboski MS. Effect of several oxygenates on regulated emissions from heavy-duty diesel engines. Environ Sci Technol 1997;31:1144-50

[7] McCormick RL, Parish R. Technical barriers to the use of ethanol in diesel fuel. Milestone report to NREL/MP-540-32674; November, 2001.

[8] Ahmed I. Oxygenated diesel: emissions and performance characteristics of ethanol-diesel blends in CI engines. SAE paper; 2001-01-2475.

[9] Lü XC, Yang JG, Zhang WG, Huang Z. Effect of cetane number improver on heat rate and emissions of high speed diesel engine fueled with ethanol-diesel blend fuel. Fuel 2004;83:2013-20.

[10] He BQ, Shuai SJ, Wang JX, He H. The effect of ethanol blended diesel fuels on emissions from a diesel engine. Atmos Environ 2003;37: 4965-71

[11] Zhang RD, He H, Shi XY, He BQ, Wang JX. Preparation and emission characteristics of ethanol-diesel fuel blends. J Environ Sci 2004;16:793-6.

[12] Gerdes KR, Suppes GJ. Miscibility of ethanol in diesel fuels. Ind Eng Chem Res 2001;40:949-56. 
[13] McCormick RL, Michael S, Graboski MS, Teresa L, Alleman TL, Andrew M, et al. Impact of biodiesel source material and chemical structure on emissions of criteria pollutants from a heavy-duty engine. Environ Sci Technol 2001;35:1742-7.

[14] Ali Y, Eskridge KM, Hanna MA. Testing of alternative diesel fuel from tallow and soybean oil in Cummins N14-410 diesel engine. Bioresour Technol 1995;53:243-54.

[15] Ali Y, Hanna MA, Borg JE. Optimization of diesel, methyl tallowate and ethanol blend for reducing emissions from diesel engine. Bioresour Technol 1995;52:237-43.

[16] Lee SW, Herage T, Yong B. Emission reduction potential from the combustion of soy methyl ester fuel blended with petroleum distillate fuel. Fuel 2004;83:1607-13.

[17] Ajav EA, Singh B, Bhattacharya TK. Experimental study of some performance of an instant speed stationary diesel engine using ethanol-diesel blends as fuel. Biomass Bioenergy 1999;17:357-65.
[18] Caro PS, Mouloungui Z, Vaitilingom G, Berge JC. Interest of combining an additive with diesel-ethanol blends for use in diesel engine. Fuel 2001;80:565-74.

[19] Özer C, İsmet Ç, Nazım U. Effects of ethanol addition on performance and emissions of a turbo charged indirect injection diesel engine running at different injection pressures. Energy Convers Manage 2004;45:2429-40.

[20] $\mathrm{Yu} \mathrm{Y,} \mathrm{He} \mathrm{H,} \mathrm{Feng} \mathrm{Q.} \mathrm{Mechanism} \mathrm{of} \mathrm{the} \mathrm{selective} \mathrm{catalytic} \mathrm{reduction}$ of $\mathrm{NO}_{x}$ by $\mathrm{C}_{2} \mathrm{H}_{5} \mathrm{OH}$ over $\mathrm{Ag} / \mathrm{A}_{2} \mathrm{O}_{3}$. Appl Catal B: Environ 2004;49: 159-71.

[21] $\mathrm{Yu} \mathrm{Y,} \mathrm{Gao} \mathrm{H,} \mathrm{He} \mathrm{H.} \mathrm{FTIR,} \mathrm{TPD} \mathrm{and} \mathrm{DFT} \mathrm{studies} \mathrm{of} \mathrm{intermediates} \mathrm{on}$ $\mathrm{Ag} / \mathrm{Al}_{2} \mathrm{O}_{3}$ during the catalytic reduction of $\mathrm{NO}$ by $\mathrm{C}_{2} \mathrm{H}_{5} \mathrm{OH}$. Catal Today 2004;93-95:805-9.

[22] He H, Yu Y, Liu J, Zhang R, Zhang C, Wang J. Selective catalytic reduction of $\mathrm{NO}_{x}$ in the presence of excess oxygen (II) with ethanol over $\mathrm{Ag} / \mathrm{Al}_{2} \mathrm{O}_{3}$. Chin J Catal 2004;25:460-6. 